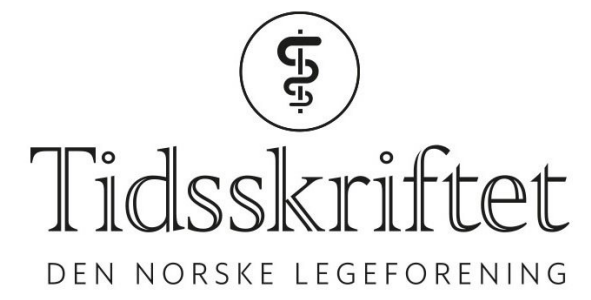

\title{
«Av alle uviktige ting i verden er fotball den viktigste»
}

KOMMENTAR

\section{KJELL ERIK STRØMSKAG}

E-post: kjeer-st@online.no

Kjell Erik Strømskag er lege tilknyttet Molde Fotballklubb.

Forfatteren har ikke oppgitt noen interessekonflikter.

«Å manøvrere i ukjent og farlig farvann krever klokskap og sindighet, ikke dårlig begrunnede bråsvinger. Det gjelder koronapandemien også. Det er så mye vi ikke vet» (1).

Jeg er glad i Tidsskriftet og leser det med stort utbytte. I papirutgaven 16/2020 som lå i postkassen min i går har sjefredaktør Are Brean en veldig god lederartikkel:

«Koronaseilasen». Den er godt begrunnet, klok og uten påstander som jeg ikke forstår.

Samtidig får jeg e-post fra Tidsskriftet. Her har Are Brean en minileder: «Fotballfeber» (2). Jeg leser den og blir forvirret og fascinert. Tilnærmingen er totalt forskjellig. Er det plattformen (papir versus nett), er det tema (vaksinasjon versus fotball), eller er det personlig engasjement (noe viktig versus noe uvesentlig), som gir den metaformosen?

Artikkelen i papirutgaven er en leder. Teksten på nett leser jeg som et innlegg på linje med de vi kan lese i VG, se på TV2 og høre i Dagsnytt 18. Det er OK. Det som forvirrer meg er hva det faglige budskapet er. Er det noe som er medisinsk galt? Er det stor smitterisiko med reisene til lagene og klubbene?

Jeg har tenkt mye på det medisinske rundt dette, og brukt mange timer på å sette meg inn i smitterisikoen. Jeg er en av tre leger tilknyttet Molde Fotballklubb. I tillegg er jeg sammen med tre lege-kolleger og en fysioterapeut medlem av Norges Fotballforbunds medisinskfaglige råd, som ble opprettet i mars i år. I rådet har vi hatt mange møter på nett, vi har diskutert, hjulpet hverandre i vanskelige saker og vært uenige. Vi var sterkt involvert i arbeidet med protokollene til Fotballforbundet (3), vi har vært pådrivere for å få i gang breddefotballen, og vi har engasjert oss for å sikre at landskamper og klubbkamper ute i Europa skulle bli trygt gjennomført. Vi har vært strenge både i dette arbeidet og i det daglige i klubbene.

Personlig har jeg vært med på reiser med klubben min til blant annet Kypros, Budapest og nå sist til London. UEFAs protokoll «Return to play» (4) er grundig og svært krevende. Sammen med denne, de norske myndighetenes krav til karatene og samarbeid med de lokale smitteoverlegene, er jeg medisinsk trygg på at de smitteforebyggingen tiltakene våre også når vi kommer fra røde land er gode nok. På reisene er vi fullstendig isolert fra andre, både under reise og opphold. Det vi gjør dokumenteres med foto og video. Det er avstand, håndvask, spriting og munnbind. Vi i klubben har nå vært teste 16 ganger. 
Om fotball i seg selv er så viktig at den bør prioriteres i den situasjonen vi er i, er en annen diskusjon. For noen er den! Jeg gjentar til slutt pave Johannes Paul II utsagn: «Av alle uviktige ting i verden er fotball den viktigste.»

LITTERATUR:

1. Brean A. Koronaseilasen. Tidsskr Nor Legeforen 2020; 140. doi: 10.4045/tidsskr.20.0866.

[PubMed][CrossRef]

2. Brean A. Fotballfeber. Tidsskr Nor Legeforen 2020; 140. doi: 10.4045/tidsskr.20.17.01. [CrossRef]

3. Norges Fotballforbund. Protokoll for gjennomføring av fotballkamper under covid-19 utbruddet 2020 - oppdatert 5. november.

https://www.fotball.no/tema/nff-nyheter/viktig-informasjon-vedrorende-koronavirus/protokoller-foraktivitet-toppfotball/protokoll-for-gjennomforing-av-fotballkamper Lest 16.11.2020

4. UEFA. Return to Play. https://www.uefa.com/returntoplay/ Lest 16.11.2020

Publisert: 14. desember 2020. Tidsskr Nor Legeforen. DOI: 10.4045/tidsskr.20.0951

(C) Tidsskrift for Den norske legeforening 2020. Lastet ned fra tidsskriftet.no 